\title{
Hypertension-related factors in patients with active and inactive acromegaly
}

\author{
Fatores implicados com a hipertensão em \\ pacientes com acromegalia ativa e inativa
}

Daniela Fedrizzi 1,2, Ticiana Costa Rodrigues ${ }^{1,2}$, Fabíola Costenaro², Rosana Scalco ${ }^{3}$, Mauro Antônio Czepielewski ${ }^{1,2}$

1 Programa de Pós-graduação em Ciências Médicas, Endocrinologia, Faculdade de Medicina, Universidade Federa do Rio Grande do Sul (UFRGS) Porto Alegre, RS, Brazi 2 Serviço de Endocrinologia, Hospital de Clínicas de Porto Alegre, Porto Alegre, RS, Brazil ${ }^{3}$ Unidade de Bioquímica, Hospital de Clínicas de Porto Alegre, Porto Alegre, RS, Brazil

Correspondence to: Mauro Antônio Czepielewski Hospital de Clínicas de Porto Alegre, Servico de Endocrinologia

Rua Ramiro Barcellos, 2350, prédio $12,4^{\circ}$ andar,

90035-003 - Porto Alegre, RS, Brazil maurocze@terra.com.br

Received on 16/July/2011 Accepted on 29/Sept/2011

\begin{abstract}
Introduction: There are several complications of the cardiovascular system caused by acromegaly, especially hypertension. Objectives: To evaluate hypertension characteristics in patients with cured/controlled acromegaly and with the active disease. Patients and methods: Cross-sectional study of the follow-up of forty-four patients with acromegaly submitted to clinical evaluation, laboratory tests and cardiac ultrasound. Patients with cured and controlled disease were evaluated as one group, and individuals with active disease as second one. Results: Forty-seven percent of the patients had active acromegaly, and these patients were younger and had lower blood pressure levels than subjects with controlled/cured disease. Hypertension was detected in $50 \%$ of patients. Subjects with active disease showed a positive correlation between IGF-1 and systolic and diastolic blood pressure levels $(r=0.48, p=0.03$; and $r=0.42, p=0.07$, respectively), and a positive correlation between IGF-1 and urinary albumin excretion (UAE) rates. In patients with active disease, IGF-1 was a predictor of systolic blood pressure, although it was not independent of UAE rate. For individuals with cured/controlled disease, waist circumference and triglycerides were the predictors associated with systolic and diastolic blood pressure. Conclusions: Our findings suggest that blood pressure levels in patients with active acromegaly are very similar, and depend on excess $\mathrm{GH}$. However, once the disease becomes controlled and IGF-1 levels decrease, their blood pressure levels will depend on the other cardiovascular risk factors. Arq Bras Endocrinol Metab. 2011;55(7):468-74
\end{abstract}

\section{Keywords}

Acromegaly; hypertension; cardiovascular risk

\section{RESUMO}

Introdução: Existem várias complicações no sistema cardiovascular causadas pela acromegalia, especialmente a hipertensão. Objetivos: Avaliar as características da hipertensão em pacientes com acromegalia curada/controlada e com doença ativa. Pacientes e métodos: Estudo transversal com 44 pacientes com acromegalia seguidos em nosso serviço. Eles foram submetidos a avaliação clínica, exames laboratoriais e ecocardiograma. Pacientes com doença curada/controlada foram avaliados como um grupo único e os indivíduos com doença ativa como outro grupo. Resultados: Quarenta e sete por cento dos pacientes apresentaram acromegalia ativa. Esses indivíduos foram mais jovens e apresentaram níveis mais baixos de pressão arterial que os indivíduos com doença controlada/ curada. A hipertensão foi detectada em $50 \%$ da amostra. Indivíduos com doença ativa mostraram uma correlação positiva entre os níveis de IGF-1 e os níveis de pressão arterial sistólica e de pressão arterial diastólica ( $r=0,48, p=0,03$; e $r=0,42, p=0,07$, respectivamente) e também apresentaram uma correlação positiva entre IGF-1 e excreção urinária de albumina (EUA). Em pacientes com doença ativa, o IGF-1 foi um preditor da pressão arterial sistólica, embora não tenha sido independente da taxa de EUA. Para indivíduos com doença curada/controlada, a circunferência da cintura e os triglicérides foram os preditores associados aos níveis de pressão arterial sistólica e diastólica. Conclusões: Nossos resultados sugerem que os níveis pressóricos em pacientes com acromegalia ativa dependem do excesso de GH. No entanto, uma vez que a doença torna-se controlada e os níveis de IGF-1 reduzem, os níveis de pressão arterial dependerão de outros fatores de risco cardiovasculares. Arq Bras Endocrinol Metab. 2011;55(7):468-74

Descritores

Acromegalia; hipertensão; risco cardiovascular. 


\section{INTRODUCTION}

A cromegaly is an endocrine disease resulting from systemic consequences of growth hormone $(\mathrm{GH})$ excess in individuals that have already reached their final height. GH excess also causes serious systemic manifestations, such as orthopedic and cardiovascular problems, sleep apnea and, probably, an increased risk of colon cancer (1).

Cardiovascular deaths are important contributors to increased mortality rates in acromegaly (1-8). At the time of diagnosis, arrhythmias, hypertension and valve diseases are present in up to $60 \%$ of patients (4). The presence of a specific acromegalic cardiomyopathy characterized by interstitial fibrosis and mediated by GH and IGF-1 has also been described (4). The coexistence of hypertension, left ventricular hypertrophy, and cardiomyopathy accounts for most of the cardiovascular impairment in acromegalic patients (9-11).

The prevalence of hypertension in acromegaly ranges from $18 \%$ to $60 \%$ in different series $(3,4,8-10,12,13)$, and its incidence is higher than in the general population. However, despite its importance, the physiopathological mechanisms of hypertension in acromegaly have not yet been well clearly established. Two recent studies have investigated the role of atherosclerosis in acromegaly by calcium score measurements, and these findings were compared to the Framingham Score $(14,15)$. These studies have shown that acromegalic patients are probably exposed to the same heart risk factors as individuals without acromegaly according to the Framingham Score.

Considering the relevance of cardiovascular disease in acromegaly, and the number of still unresolved issues in its pathogenesis, we carried the present study out to evaluate hypertension in a cohort of patients with acromegaly.

\section{PATIENTS AND METHODS}

\section{Methods}

A cross-sectional study was performed in patients with acromegaly who were followed up at the Division of Endocrinology of the Hospital de Clínicas de Porto Alegre (HCPA). This study was approved by the Research Ethics Committee of HCPA (05-513). All the patients signed an informed consent form.

\section{Patients}

Initially, 52 acromegalic patients were selected. However, eight were excluded: four of them because of clinical conditions that prevented changes in anti-hypertensive regimen and/or removal of diuretics (three of them had serious cardiac disease; one had renal failure). Three patients refused to join the study, and one patient showed poor compliance with the proposed algorithm. Therefore, 44 patients were included.

\section{Clinical evaluation}

Clinical assessment consisted of acromegaly-focused medical history; weight, height and abdominal circumference measurement; blood pressure; and routine clinical cardiac examination. The patient was considered hypertensive if systolic blood pressure was $>140$ $\mathrm{mmHg}$ or diastolic blood pressure was $>90 \mathrm{mmHg}$ in two consecutive measurements at the office, confirmed by home measurements; or if there was previous history of anti-hypertensive medication (16). Obesity was determined by body mass index $(\mathrm{BMI}) \geq$ $30 \mathrm{~kg} / \mathrm{m}^{2}$ (17); abdominal circumference above $80 \mathrm{~cm}$ in women and above $94 \mathrm{~cm}$ in men were considered visceral obesity (18). Patients who consumed nicotine cigarettes on a regular basis during the period of data collection were considered current smokers. Diabetes mellitus was diagnosed by the American Diabetes Association criteria $(18,19)$, or by current use of oral antidiabetics and/or insulin. Homeostasis Model Assessment of Insulin Resistance (HOMA-IR) was calculated as follows: [glucose $(\mathrm{mmol} / \mathrm{L}) \times 18 \mathrm{x}$ insulin $(\mu \mathrm{UI} / \mathrm{mL})]$.

Patients were classified according to presence of cardiovascular risk factors; these included obesity, diabetes mellitus, smoking, low HDL, high LDL, hypertension and abdominal obesity. Abnormal laboratory test results were: total cholesterol above $200 \mathrm{mg} / \mathrm{dL}$, HDLcholesterol $\leq 40 \mathrm{mg} / \mathrm{dL}$ for both male and female subjects, LDL-cholesterol above $130 \mathrm{mg} / \mathrm{dL}$ (or $100 \mathrm{mg}$ / $\mathrm{dl}$ for diabetic patients) and triglycerides above 150 $\mathrm{mg} / \mathrm{dL}(18,20)$. Patients who were using angiotensin-converting enzyme inhibitors (ACEi), angiotensin II blockers or diuretics, and whose clinical condition allowed it, had these drugs replaced, if necessary, by antihypertensive drugs of different pharmacological classes - amlodipine was the drug used in most cases. Next, a new visit was scheduled for laboratory tests, with at least 1 -month interval. In the meantime, all the 
patients were requested to perform two-dimensional Doppler cardiac ultrasound.

\section{Laboratory measurements}

Laboratory tests were performed in fasting patients in upright position. PRA and aldosterone samples were collected individually, and immediately sent to the laboratory, where they were centrifuged and frozen.

The following diagnostic kits were used: PRA: Adaltis - Casalecchio di Reno, Italy (normal range for orthostatic position: $0.98-4.18 \mathrm{ng} / \mathrm{mL} / \mathrm{h})$. Aldosterone: DSL - Diagnostic Systems Laboratories, Inc. Webster, Texas, USA (normal range for orthostatic position $3.81-31.33 \mathrm{ng} / \mathrm{dL})$.

IGFl: DSL - Diagnostic Systems Laboratories, Inc. Webster, Texas, USA (interassay coefficient of variation - CV: $8.2 \%, 1.5 \%$ and 3.7\%; intrassay CV: $3.4 \%, 3.0 \%$ and $1.5 \%$, for low, medium and high points of the standard curve, respectively. Normal range for men: 1820 yrs: $197-956 \mathrm{ng} / \mathrm{mL} ; 20-23$ y: $215-628 \mathrm{ng} / \mathrm{mL}$; $23-25$ y: $169-591 \mathrm{ng} / \mathrm{mL} ; 25-30$ y: $119-476 \mathrm{ng} / \mathrm{mL}$; 30-40 y: 100-494 ng/mL. Normal range for women: $18-20$ y: $193-575 \mathrm{ng} / \mathrm{mL} ; 20-23$ y: $110-521 \mathrm{ng} / \mathrm{ml}$; 23-25 y: 129-480 ng/mL; 25-30 y: 96-502 ng/mL; 30-40 y: 130-354 ng/mL. Normal range for both sexes for 40-year old or more: 40-50 y: 101-303 ng/mL; 50-70 y: 78-258 ng/mL). For statistical calculations, we also used the variable \% ULN, which expresses the percentage of IGF-1 level that is above the upper limit of normality. This was done to eliminate IGF-1 variation according to age.

GH: Euro/DPC - SIEMENS - Llanberis, United Kingdom (normal range: $0.5-5.0 \mathrm{ng} / \mathrm{mL}$ ). Glucose, total cholesterol, HDL cholesterol, triglycerides, creatinine, sodium, potassium and microalbuminuria: Modular P - Roche Diagnostics, Mannheim, Germany. Albumin excretion rate (AER) was measured by immunoturbidimetry (Microal; Ames-Bayer, Tarrytown, NY; intra- and interassay coefficients of variation of $4.5 \%$ and $11 \%$, respectively). Normoalbuminuria was determined by AER < $30 \mathrm{mg} / 24 \mathrm{~h}$; microalbuminuria between 31-300 mg/24h; and macroalbuminuria AER > $300 \mathrm{mg} / 24 \mathrm{~h}$. Insulin: Modular E - Roche Diagnostics, Mannheim, Germany (normal range, 2.3 a $24.9 \mu \mathrm{UI} /$ $\mathrm{mL}$ ); and ultra-sensitive $\mathrm{C}$ reactive protein (us-CRP): Nefelometer - Dade Behring, Marburg, Germany.

Cardiac ultrasound was performed in an equipment with adult-type $3 \mathrm{MHz}$ transducers. The following parameters and echocardiographic measures were evalu- ated: ejection fraction, parietal thicknesses, left ventricular mass, contractility, valves. Left ventricular mass index $(\mathrm{LVMi}) \geq 110 \mathrm{~g} / \mathrm{m}^{2}$ for women, and $\geq 135 \mathrm{~g} / \mathrm{m}^{2}$ for men were considered as increased left ventricular mass $(21)$.

\section{Classification criteria for acromegaly}

Criteria for cured acromegaly were nadir $\mathrm{GH}<0.4 \mathrm{ng} /$ $\mathrm{mL}$ in oral glucose tolerance test (OGTT); basal GH below $<1 \mathrm{ng} / \mathrm{mL}$; and normal IGF-l for age and gen$\operatorname{der}(22)$ in patients with no medication for acromegaly. Patients with normal IGF-1 for age and gender and basal GH below $1 \mathrm{ng} / \mathrm{mL}$ on any medication for acromegaly were considered to have controlled disease; patients with contradictory results (IGF-I and GH basal in disagreement) were considered as having controlled disease, based on the IGF-1 levels. Patients with none of the criteria above were considered as having active disease.

\section{Statistical analysis}

Categorical variables were described as absolute and relative frequencies, and quantitative variables as means and standard deviation. The Mann-Whitney test was used for comparisons between variables with asymmetrical distributions. Spearman's correlation was used for correlations between variables with asymmetrical distributions, and Pearson's correlation for variables with normal distribution. Linear regression was used to estimate the predictors of the blood pressure levels. SSPS 16.0 (Chicago, IL) was used for the statistical analyses.

\section{RESULTS}

\section{Characteristics of the sample}

Among the 44 patients, 24 were males. Mean age was $50 \pm 9$ years. Mean BMI was $28 \pm 5 \mathrm{~kg} / \mathrm{m}^{2} ; 29.5 \%$ of subjects were obese, and $82.6 \%$ of the men had visceral obesity, against $85 \%$ of the women. Hypertension was found in $50 \%$ of the sample, and diabetes was found in $18.2 \%$ of the patients. Fourteen patients had left ventricular hypertrophy $(31.8 \%)$. According to the lipid profile, $47.7 \%(21 / 44)$ had high total cholesterol; $22.2 \%$ had low HDL cholesterol ( 5 females and 5 males); $40.9 \%$ (18/44) had high LDL cholesterol and 25\% $(11 / 44)$ had high triglycerides. Five patients (11.4\%) had microalbuminuria. 
All patients in this cohort underwent transsphenoidal surgery, except one (on octreotide). Eight subjects underwent radiotherapy, 27 were on octreotide, and 11 were on cabergoline (only one subject was only taking cabergoline). In the entire cohort, 16 had some degree of hypopituitarism: 12 had hypogonadism, 10 had hypothyroidism and one had hypocortisolism. All of these patients were under hormonal replacement with well-controlled deficiencies.

Active acromegaly was present in $47.7 \%$ of the patients. Table 1 shows the clinical and laboratory characteristics of the subjects according to disease status. Patients with active disease were younger and less hypertensive than subjects with controlled/cured disease.

Among cure/controlled patients $(\mathrm{n}=23), 13(56.5 \%)$ were cured with no medication and 10 (43.5) had the condition controlled by medication: eight patients had normal IGF- 1 and high basal GH $(1.0<\mathrm{GH}<2.5 \mathrm{ng} / \mathrm{mL})$.

Table 1. Clinical and laboratory characteristics stratified by acromegaly status

\begin{tabular}{lccc}
\hline & $\begin{array}{c}\text { Active } \\
(\mathbf{n = 2 1 )}\end{array}$ & $\begin{array}{c}\text { Cured/Controlled } \\
(\mathbf{n = 2 3})\end{array}$ & $\mathbf{p}$ \\
\hline Male (n) & 12 & 12 & 0.74 \\
Age (years) & $48 \pm 9$ & $55 \pm 8$ & 0.01 \\
BMI (kg/m²) & $30 \pm 6$ & $27 \pm 3$ & 0.16 \\
Circumference (cm) & $100 \pm 13$ & $95 \pm 8$ & 0.24 \\
Hypertension (\%) & $33 \%$ & $65 \%$ & 0.03 \\
Diabetes (\%) & $19 \%$ & $13 \%$ & 0.58 \\
Smoking & $44 \%$ & $36 \%$ & 0.85 \\
TC (mg/dL) & $194 \pm 47$ & $195 \pm 39$ & 0.90 \\
HDL (mg/dL) & $53 \pm 19$ & $56 \pm 13$ & 0.57 \\
LDL (mg/dL) & $106 \pm 42$ & $116 \pm 35$ & 0.79 \\
TG (mg/dL) & $104(56-548)$ & $114(48-250)$ & 0.54 \\
HOMA-IR & $7.95 \pm 21.9$ & $1.09 \pm 0.79$ & 0.41 \\
AER (mg/24h) & $1.55(0.0-755)$ & $0.10(0.0-420)$ & 0.83 \\
us-CRP & $1.49 \pm 2.22$ & $2.36 \pm 3.08$ & 0.55 \\
LVH & $14 \%$ & $21 \%$ & 0.81 \\
\%ULN & $42(1-493)$ & $-32(-74-7.0)$ & $<0.001$ \\
IGF-1 & $429(161-1799)$ & $196(75-294)$ & $<0.001$ \\
\hline
\end{tabular}

Variables are shown as means and standard deviation, or absolute values or percentages (\%), or as median and upper and lower limits. BMl: body mass index; HOMA-IR: homeostasis model assessmentinsulin resistance; AER: albumin excretion rate; us-CRP: ultra-sensitive C-reactive protein; LVH: left ventricular hypertrophy. \%ULN: percentage above upper limit of normality of IGF-1 level.

\section{Aggregation of cardiovascular risk factors}

Patients were evaluated according to the presence of traditional cardiovascular risk factors. Thirty patients had low cardiovascular risk, 12 had moderate risk, and only 2 patients had high cardiovascular risk according to the Framingham Score. There was no correlation between number of risk factors and basal GH $(r=0.102$; $\mathrm{p}=0.53)$, or IGF-1 levels $(\mathrm{r}=-0.01 ; \mathrm{p}=0.95)$.

\section{Hypertension and ventricular hypertrophy}

When the entire group was evaluated according to hypertension status, there was no difference between mean IGF-1 and basal GH in normotensive and hypertensive patients. Normotensive patients had median IGF- $\mathrm{l}=325 \mathrm{ng} / \mathrm{mL}$; hypertensive patients had median IGF-l $=221 \mathrm{ng} / \mathrm{mL}(\mathrm{p}=0.25)$. For basal $\mathrm{GH}$, means were $4 \mathrm{ng} / \mathrm{mL}$ in normotensive patients, and $2 \mathrm{ng} / \mathrm{mL}$ in hypertensive patients $(\mathrm{p}=0.31)$. Concerning cardiac hypertrophy, there was no statistically significant difference between IGF-1 levels $(244 \mathrm{ng} / \mathrm{mL}$ in patients without $\mathrm{LVH}$, and $252 \mathrm{ng} / \mathrm{mL}$ in patients with $\mathrm{LVH}$; $\mathrm{p}=0.84)$, and basal GH levels ( $1.1 \mathrm{ng} / \mathrm{mL}$ in patients without $\mathrm{LVH}$, and $0.94 \mathrm{ng} / \mathrm{mL}$ in patients with $\mathrm{LVH}$; $\mathrm{p}=0.78)$. There was no difference regarding nadir $\mathrm{GH}$ during OGTT ( $1 \mathrm{mg} / \mathrm{dL}$ vs. $1 \mathrm{mg} / \mathrm{dL}$, for subjects with $\mathrm{LVH}$ and without $\mathrm{LVH}$ respectively, $\mathrm{p}=0.91$ ). Additionally, when we used the variable \%ULN for comparisons between hypertensive and normotensive individuals, there was no difference in \%ULN between both groups. Again, when evaluating the presence of $\mathrm{LVH}$, there was no correlation between $\mathrm{LVH}$ and age $(\mathrm{r}=0.26, \mathrm{p}=0.08)$, even when statistically controlling for disease activity $(\mathrm{r}=0.25, \mathrm{p}=0.11)$.

\section{Renin-aldosterone axis}

There was no correlation between PRA and IGF-1 $(\mathrm{r}$ $=-0.12 ; \mathrm{p}=0.46)$, basal GH $(\mathrm{r}=-0.12 ; \mathrm{p}=0.46)$, or nadir OGTT $(\mathrm{r}=-0.18 ; \mathrm{p}=0.28)$. There was also no significant correlation between aldosterone or aldosterone-PRA ratio (ARR) and the same parameters of acromegaly activity. Correlation between aldosterone and IGF- 1 showed: $\mathrm{r}=0.03 ; \mathrm{p}=0.85$. Correlation between aldosterone and basal GH showed: $\mathrm{r}=-0.148$; $\mathrm{p}=0.34$, and the correlation between aldosterone and nadir OGTT showed $\mathrm{r}=-0.131 ; \mathrm{p}=0.44$. Results for the correlations with ARR were for IGF- $1, \mathrm{r}=0.09$ and $\mathrm{p}=0.57 \mathrm{l}$; for basal GH, $\mathrm{r}=0.09$ and $\mathrm{p}=0.57$; for nadir OGTT, $\mathrm{r}=0.16$ and $\mathrm{p}=0.34$.

\section{Renin-aldosterone axis and hypertension}

There were no significant relationships or differences between hypertensive and normotensive groups re- 
garding aldosterone levels and aldosterone-PRA ratio. There was a statistically significant difference only in PRA levels between hypertensive patients $(2.31 \mathrm{ng} /$ $\mathrm{mL} / \mathrm{h})$ and normotensive patients $(6.08 \mathrm{ng} / \mathrm{mL} / \mathrm{h})$, $\mathrm{p}=0.01$. However, there was no difference between patients with active and non-active disease $(\mathrm{p}=0.59)$.

\section{Microalbuminuria, HOMA-IR and us-CRP vs. acromegaly status and hypertension}

There was no statistical difference between microalbuminuria and us-CRP levels between hypertensive and normotensive patients (UAE rate in normotensive patients $=2.72 \mathrm{mg} / 24 \mathrm{~h}$, and in hypertensive patients $=64.2 \mathrm{mg} / 24 \mathrm{~h} ; \mathrm{p}=0.14$; us-CRP in normotensive patients $=1.74 \mathrm{mg} / \mathrm{dL}$, and in hypertensive patients $=2.05 \mathrm{mg} / \mathrm{dL} ; \mathrm{p}=0.76)$, or between patients with active and controlled acromegaly. However, there was a correlation between IGF- 1 and UAE levels $(r=0.33$, $\mathrm{p}=0.04)$, and between IGF- 1 and HOMA-IR index $(\mathrm{r}=0.419, \mathrm{p}=0.006)$.

When we stratified patients by acromegaly status, those with active disease had a positive correlation between IGF-1 and systolic and diastolic blood pressure levels $(\mathrm{r}=0.48, \mathrm{p}=0.03$, and $\mathrm{r}=0.42, \mathrm{p}=0.07$, respectively), and a positive correlation between IGFl and UAE rate $(\mathrm{r}=0.66, \mathrm{p}=0.004)$. We did not find any correlation between these variables in patients with cured/controlled disease. However, in patients with cured/controlled disease, systolic blood pressure was positively correlated with BMI $(\mathrm{r}=0.43, \mathrm{p}=0.04)$, with triglycerides $(\mathrm{r}=0.57, \mathrm{p}=0.004)$, and waist circumference $(\mathrm{r}=0.54, \mathrm{p}=0.008)$; and diastolic blood pressure was positively correlated with BMI $(\mathrm{r}=0.43$, $\mathrm{p}=0.02)$, waist circumference $(\mathrm{r}=0.65, \mathrm{p}=0.001)$, and triglycerides $(\mathrm{r}=0.46, \mathrm{p}=0.02)$.

A linear regression was performed for individuals with active disease including age and BMI (because of their biological importance) and IGF-1 as predictors, and systolic blood pressure as the dependent variable. Only IGF-1 was an independent predictor of systolic blood pressure (Beta estimate $=0.52, \mathrm{p}=0.04$ ) . Curiously, IGF-1 was no longer a predictor when UAE rate was included in the model, suggesting that IGF-1 has its effect on hypertension mediated by albuminuria.

For individuals with controlled disease, a similar regression model showed different results: waist circumference and triglycerides were the predictors associated with systolic blood pressure, independent of age (in two separate models, BMI was not included, due to the interaction between BMI, waist circumference and triglyceride levels); for diastolic blood pressure, triglycerides and waist circumference were predictors, in two different age-adjusted models.

\section{DISCUSSION}

This study reports the main characteristics of a group of acromegalic patients from a cardiovascular perspective. Of the 44 patients, 21 (47.7\%) had active acromegaly. Prevalence of hypertension was similar to the prevalence described in the literature (between 18\%$60 \%)(8,12,23)$. It is known that acromegalic patients develop cardiomyopathy, hypertension and diabetes, in addition to other complications $(6,24,25)$. Our patients with active acromegaly did not have a greater number of cardiovascular risk factors than those with cured/ controlled disease. Possible reasons for this finding are: our sample with active disease was younger than cured/ controlled patients, and absence of a control group for additional comparisons.

Although not the only factor responsible for cardiac involvement in acromegaly, the coexistence of high blood pressure levels worsens the effects of acromegalic cardiomyopathy (10), as previously observed (11). There were no differences between hypertensive and normotensive acromegalic patients regarding $\mathrm{GH}$ and IGF-1 levels; patient with active acromegaly were less frequently hypertensive than those with cured/controlled disease. The presence of younger patients with active acromegaly and older patients with controlled acromegaly could explain this finding. However, in patients with active acromegaly, IGF-1 was a predictor of systolic blood pressure levels and albuminuria was a possible mediator, while in patients with controlled disease, other factors were associated with blood pressure levels, including metabolic syndrome components, such as triglycerides and abdominal obesity.

There was no difference in hormonal levels between patients with and without left ventricular hypertrophy, different from information in the literature (26-28). Previous studies have associated GH and IGF-1 excess with increased activity of the renin-aldosterone axis in acromegaly, such as the study by Mulatero and cols. (36). Increased PRA and aldosterone levels could account for the occurrence of hypertension in patients with acromegaly. However, there was no correlation between GH and IGF-1 levels, and PRA and aldosterone levels. Analysis of PRA, aldosterone and aldosterone- 
-PRA ratio in hypertensive and normotensive patients showed higher levels of PRA in normotensive acromegalic patients. It should be emphasized that treatment with all drugs interfering with the renin-aldosterone axis were discontinued in hypertensive patients at least 1 month before hormonal dosages. Lower PRA levels in hypertensive patients, compared to normotensive ones, could suggest a relative plasma volume expansion in hypertensive patients, caused by GH excess, leading to elevated arterial pressure.

Microalbuminuria has also stood out as an important marker of cardiovascular disease $(29,30)$. Microalbuminuria has been associated with an increased risk of cardiovascular events in diabetic patients (31), as well as in non-diabetic patients (32). There are data showing increased levels of albuminuria in acromegaly (33). There is evidence that acromegaly has a major effect on the kidneys, more exactly on glomerular filtration and renal plasma flow (34), and this effect is a consequence of IGF-1 activity (35). Although our findings did not enable etiological hypotheses about the renal effects of the somatotrophic axis, they suggest a possible mediator effect of IGF- 1 and albuminuria on blood pressure levels. Considering the aforementioned implications of increased renal albumin excretion in the occurrence of cardiovascular events, it is possible to argue that acromegaly increases cardiovascular risk. Similarly, analysis of insulin resistance in our patients, measured by the HOMA-IR index, also showed a correlation between this factor and IGF-1 levels.

Our findings suggest that blood pressure levels in the patients with active acromegaly are very similar, and depend on excess GH. However, once the disease has been controlled and IGF-1 levels decrease, their blood pressure levels will depend on other cardiovascular risk factors. These subjects should be strictly and insistently treated for these factors and followed up for long time.

Disclosure: no potential conflict of interest relevant to this article was reported.

\section{REFERENCES}

1. Holdaway IM, Rajasoorya RC, Gamble GD. Factors influencing mortality in acromegaly. J Clin Endocrinol Metab. 2004;89(2):667-74.

2. Katznelson L. Current thinking on the management of the acromegalic patient. Curr Opin Endocrinol Diabetes Obes. 2007;14(4):311-6.

3. Colao A, Ferone D, Marzullo P, Lombardi G. Systemic complications of acromegaly: epidemiology, pathogenesis, and management. Endocr Rev. 2004;25(1):102-52.
4. Melmed S. Medical progress: Acromegaly. N Engl J Med. 2006;355(24):2558-73.

5. Vitale G, Pivonello R, Lombardi G, Colao A. Cardiac abnormalities in acromegaly. Pathophysiology and implications for management. Treat Endocrinol. 2004;3(5):309-18.

6. Clayton RN. Cardiovascular function in acromegaly. Endocr Rev. 2003;24(3):272-7.

7. Otsuki M, Kasayama S, Yamamoto H, Saito H, Sumitani S, Kouhara $\mathrm{H}$, et al. Characterization of premature atherosclerosis of carotid arteries in acromegalic patients. Clinical endocrinology. 2001;54(6):791-6.

8. Mestron A, Webb SM, Astorga R, Benito P, Catala M, Gaztambide $\mathrm{S}$, et al. Epidemiology, clinical characteristics, outcome, morbidity and mortality in acromegaly based on the Spanish Acromegaly Registry (Registro Espanol de Acromegalia, REA). Eur J Endocrinol. 2004;151(4):439-46.

9. Melmed S. Acromegaly. In: Melmed S, ed.The Pituitary: Blackwell Publishing 2002:419-54.

10. Lopez-Velasco R, Escobar-Morreale HF, Vega B, Villa E, Sancho JM, Moya-Mur JL, et al. Cardiac involvement in acromegaly: specific myocardiopathy or consequence of systemic hypertension? J Clin Endocrinol Metab. 1997;82(4):1047-53.

11. Casini AF, Araújo PB, Fontes R, Xavier SS, Gadelha MR. Alterações morfológicas e funcionais cardíacas e análise dos fatores determinantes de hipertrofia ventricular esquerda em 40 pacientes com acromegalia. Arq Bras Endocrinol Metab. 2006;50:82-90.

12. Vitale G, Pivonello R, Auriemma RS, Guerra E, Milone F, Savastano $S$, et al. Hypertension in acromegaly and in the normal population: prevalence and determinants. Clinical Endocrinology. 2005;63(4):470-6.

13. Andreassen M, Faber J, Vestergaard H, Kistorp C, Kristensen LO. $\mathrm{N}$-terminal pro-B-type natriuretic peptide in patients with growth hormone disturbances. Clin Endocrinol (Oxf). 2007;66(5):619-25.

14. Bogazzi F, Battolla L, Spinelli C, Rossi G, Gavioli S, Di Bello V, et al. Risk factors for development of coronary heart disease in patients with acromegaly: a five-year prospective study. J Clin Endocrinol Metab. 2007;92(11):4271-7.

15. Akutsu1 H, Kreutzer1 J, Wasmeier G, Ropers D, Rost C, Möhlig M, et al. Acromegaly per se does not increase the risk for coronary artery disease. Eur J Endocrinol. 2010;162:879-86.

16. Chobanian AV, Bakris GL, Black HR, Cushman WC, Green LA, Izzo $\mathrm{JL} J \mathrm{r}$, et al. The Seventh Report of the Joint National Committee on Prevention, Detection, Evaluation, and Treatment of High Blood Pressure: the JNC 7 report. JAMA. 2003;289(19):2560-72.

17. Clinical Guidelines on the Identification, Evaluation, and Treatment of Overweight and Obesity in Adults--The Evidence Report. National Institutes of Health. Obes Res. 1998;6 Suppl 2:51S-209S.

18. Alberti KG, Zimmet $P$, Shaw J. The metabolic syndrome--a new worldwide definition. Lancet. 2005;366(9491):1059-62.

19. Genuth S, Alberti KG, Bennett P, Buse J, Defronzo R, Kahn R, et al. Follow-up report on the diagnosis of diabetes mellitus. Diabetes Care. 2003;26(11):3160-7.

20. Third Report of the National Cholesterol Education Program (NCEP) Expert Panel on Detection, Evaluation, and Treatment of High Blood Cholesterol in Adults (Adult Treatment Panel III) final report. Circulation. 2002;106(25):3143-421.

21. Devereux RB. Detection of left ventricular hypertrophy by M-mode echocardiography. Anatomic validation, standardization, and comparison to other methods. Hypertension. 1987;9(2 Pt 2):II19-26.

22. Giustina $A$, Chanson $P$, Bronstein MD, Klibanski $A$, Lamberts $S$, Casanueva FF, et al.; Acromegaly Consensus Group. A consensus on criteria for cure of acromegaly. J Clin Endocrinol Metab. 2010;95(7):3141-8.

23. Minniti G, Moroni C, Jaffrain-Rea ML, Bondanini F, Gulino A, Cassone $\mathrm{R}$, et al. Prevalence of hypertension in acromegalic patients: 
clinical measurement versus 24-hour ambulatory blood pressure monitoring. Clin Endocrinol. 1998;48(2):149-52.

24. Sacca L, Cittadini A, Fazio S. Growth hormone and the heart. Endocr Rev. 1994;15(5):555-73.

25. Rodrigues EA, Caruana MP, Lahiri A, Nabarro JD, Jacobs HS, Raftery EB. Subclinical cardiac dysfunction in acromegaly: evidence for a specific disease of heart muscle. Br Heart $\mathrm{J}$. 1989;62(3):185-94.

26. Minniti G, Jaffrain-Rea ML, Moroni C, Baldelli R, Ferretti E, Cassone $\mathrm{R}$, et al. Echocardiographic evidence for a direct effect of $\mathrm{GH} / \mathrm{IGF}-\mathrm{I}$ hypersecretion on cardiac mass and function in young acromegalics. Clin Endocrinol. 1998;49(1):101-6.

27. Vitale G, Galderisi M, Pivonello R, Spinelli L, Ciccarelli A, de Divitiis $\mathrm{O}$, et al. Prevalence and determinants of left ventricular hypertrophy in acromegaly: impact of different methods of indexing left ventricular mass. Clin Endocrinol. 2004;60(3):343-9.

28. Colao A, Marzullo P, Di Somma C, Lombardi G. Growth hormone and the heart. Clin Endocrinol. 2001;54(2):137-54.

29. Weir MR. Microalbuminuria and cardiovascular disease. Clin J Am Soc Nephrol. 2007;2(3):581-90.

30. Gerstein HC, Mann JF, Yi Q, Zinman B, Dinneen SF, Hoogwerf $\mathrm{B}$, et al. Albuminuria and risk of cardiovascular events, death, and heart failure in diabetic and nondiabetic individuals. JAMA. 2001;286(4):421-6.

31. Gross JL, de Azevedo MJ, Silveiro SP, Canani LH, Caramori ML, Zelmanovitz T. Diabetic nephropathy: diagnosis, prevention, and treatment. Diabetes Care. 2005;28(1):164-76.

32. Arnlov J, Evans JC, Meigs JB, Wang TJ, Fox CS, Levy D, et al. Low grade albuminuria and incidence of cardiovascular disease events in nonhypertensive and nondiabetic individuals: the Framingham Heart Study. Circulation. 2005;112(7):969-75.

33. Baldelli R, De Marinis L, Bianchi A, Pivonello R, Gasco V, Auriemma $R$, et al. Microalbuminuria and insulin sensitivity in patients with growth hormone-secreting pituitary tumor. J Clin Endocrinol Metab. 2008;93(3):710-4

34. Feld S, Hirschberg R. Growth hormone, the insulin-like growth factor system, and the kidney. Endocr Rev. 1996;17(5):423-80.

35. O'Shea MH, Layish DT. Growth hormone and the kidney: a case presentation and review of the literature. J Am Soc Nephrol. 1992;3(2):157-61.

36. Mulatero $P$, Veglio F, Maffei $P$, Bondanelli M, Bovio S, Daffara $F$, et al. CYP11B2-344T/C gene polymorphismand blood pressure in patients with acromegaly. J Clin Endocrinol Metab. 2006;91(12):5008-12. 